\title{
Manufacturing problems and Solutions of Natural Fiber Reinforced Composites
}

\author{
${ }^{a}$ *Ahmer Hussain Shah, ${ }^{\text {a }}$ Abdul Qadeer Dayo, ${ }^{\text {a }}$ Raja Asif Wagan, ${ }^{a}$ Ahthasham Sajid, ${ }^{\text {a }}$ Azizullah Shaikh, ${ }^{\text {b }}$ Ghazanfar \\ Mehdi, \\ ${ }^{a}$ Balochistan University of Information Technology, Engineering and Management Sciences, Quetta 87300, Pakistan \\ ${ }^{\mathrm{b}}$ Faculty of Engineering, Science and Technology, Indus University Karachi, Pakistan \\ * Corresponding author. Tel.: +92-3332546991 \\ E-mail: ahmmer.shah@buitms.edu.pk, drahmershah@yahoo.com
}

\begin{abstract}
In the modernworld, natural fiber reinforced polymer composites (NFRP) are gaining too much attention due to thelower manufacturing cost and favorable effects on the environment after use. Besides this, the processing problems ofsuch materials always remain a challenge. The bio/natural fiber has some protective layers and coatings causing hindrance for good interactions with polymer for good performance characteristics. Although numerous processes are already developed for overcoming the processing parameters but the desired goals are still not achieved. This short review focus on some useful properties and pre-treatment of fibers used for the manufacturing NFRP along with problems associated with effective remedial solutions. The viewers of this paper will get the basic knowledge and may select the area to study further in this field.
\end{abstract}

Keywords: Natural fiber, composites, treatment of fiber, hybridization of composites.

Date Received 27-08-2019

Date Accepted 25-12-2019

Date Published 31-12-2019

\section{INTRODUCTION}

Talking about composites, NFRP are considered to be most influential material in the modern world as compared to synthetic materials due to their lower cost and improved sustainability [1]. This implies the significant use of such materials for the manufacturing of biodegradable material. On the other hand, the use of biomaterial is not new to mankind; numbers of historical archives confirmed their existence. The bricks used in Great Wall of China were made strong by mixing clay, reeds, twigs, branched willow and sands (biocomposite). Likewise, same is employed for natural polymers as paper and silk are known to humans since early history.

Since the development of synthetic materials in the $19^{\text {th }}$ century, the application of synthetic material enhanced. However, the issues related to disposal of the end product, costly dumping or environmental concerns on the incineration reduced the feasibility [2]. The importance of natural fiber materials in the field of high-performance polymeric composites was realized since the start of $21^{\text {st }}$ century. Furthermore, plastic production is based on utilizing oil-based substances which are nonrenewable.

For the application of composites, not requiring high properties, an alternative method can be employed to fulfill the needs by using such materials in the composites having minimum impact on the discussed issues. Material scientists used the term "ecocomposites" or "green composites". These materials are based on the fact that many of the typical applications do not require excellent mechanical behavior; while fulfills the needs for some secondary applications like panels, packaging, cases, gardening items[3, 4].

Based on the above statements, it is necessary to discuss here some materials. The first used material in this concern was recyclable polymers (polyolefin) with the addition of organic fillers. The use of such materials replaced many nonbiodegradable or nonrenewable polymers. Polyolefin polymers like polypropylene (PP) and polyethylene (PE) are most widely used among others. These fall under the category of thermoplastics. Besides this, another class of polymer matrices is also important, especially when concerning mechanical performances. Polyesters, epoxies, andphenolbased polymers fall into the category of thermosets. Thermosets have higher mechanical properties than the thermoplastics [5]. Organic fillers are preferred over inorganic fillers. Fillers from the wastes reduce the overall cost of the composite on one hand and have comparatively less negative effects on health issues of the workers, are easy to be burned/damped or incinerated and also have lower specific weights, allowing them to be effectively incorporated for good thermal and sound insulations [6-11].

Wood is the well-known material for filler application. It can easily be obtained from any saw dust mill. It can easily be crushed into required size depending upon intended application by simple grinding procedures. Besides, there is a variety of fibers that can be employed as filler. High mechanical performance is usually directly proportional with cellulose content and also on the alignment of microfibrils in length. Most of themfallinto the category of stem fibers which include 
cellulose-based fibers such as jute, sisal, flax, kenaf, ramie, hemp, etc. $[9,12]$

This paper provides a brief overview of natural fiber based polymer composites along with problems in the processing of the fibers. The role of most important cellulose-based fibers like jute, kenaf, sisal, hemp as a filler in polymer matrices is discussed briefly to provide basic knowledge to the beginners in the field of NFRP.

\section{DISCUSSION}

\section{Problems of NFRP composites processability}

\section{A. Rheological problems}

The flow of resin is primarily important for commercial applications. As a general rule, increasing the fiber content in the resin increases the viscosity of polymer, leading towards the processability problems [13-16]. This problem is often observed in the processing of short fibers composites as compared to the sheet of fibers. By using a bit longer fibers, this issue can be resolved to some extent.

Rheology studies of the PE and PP composites with wood flour were investigated. Researchers found that viscosity is related to the filler content percentage and not on type of fiber being used [16]. However, it cannot be neglected that interaction of fibers with polymers has a strong relation with the viscosity of matrix. For instance, gelation of matrix material is also effected especially when dealing with thermosets. Addition of chemically modified fiber affects the gelation by catalyzing or retarding the reaction of reactive components during polymerization reaction or network formation [17]. For fiber based composites, gelation is a key factor to control the properties which is usually accompanied by good wetting of fibers before starting of gelation.

Addition of maleicanhydride adhesion promoter can significantly alter the rheological behavior of fibers with the matrix by forming filler-polymer bonds [18]. The addition of short fiber to a matrix at a certain level reaches to form clumps and balls usually called as neps. These entanglements limit the addition of fibers to cementitious composites [19]. It was also noted that the fibers aspect ratio is responsible for this [20] and the level of filler addition is dependent on it.

\section{B. Fiber surface problems}

All natural fibers are hygroscopic in nature i.e. water loving. At room temperature, natural fibers tend to absorb/adsorb a certain quantity of moisture from the environment. This moisture can negatively affect the interaction of fiber with the matrix. The equilibrium moisture contents of the natural fibers are shown in Table 1 [21].The overall performance of fiber can be increased by making the hydrophobic surface. The hydrophobicity of fiber can be by certain treatments. The treatment with silane coupling is the most suitable option. This only changes the water absorption rate while moisture regain of the fiber does not change because the cell walls do not absorb these compounds. On the other hand, coating treatment changes the pore size thereby covering the hydroxyl groups thus decreasing water sorption[22]. Water contact angle of fibers is increased by these treatments which can be determined by dynamic contact angle test [23]. Polar component of the fiber decreases while nonpolar component increases [24, 25]. Treated fibers show smooth surface pattern than untreated fibers[26]. Polar amino groups only slightly alter the moisture content because of highly hydrophilic properties of amino end group [24].

In order to overcome the moisture uptake of natural fiber, material scientists have tried to convert these hydrophilic bonds with some reactive agents known as Silane coupling agents [27]. Fig.1 shows a basic mechanism that how these compounds work.

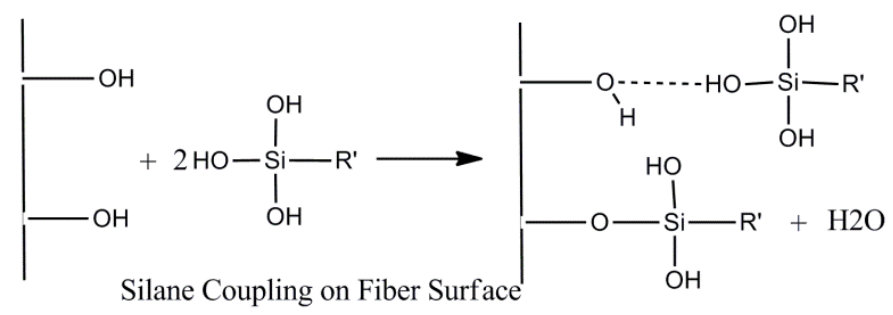

Fig.1.The reaction of silane coupling agents with Natural fiber [28].

Besides this, there are many techniques available to overcome the issues of hydrophilicity of fibers like acetylation, stearic acid treatment, benzylation, TDI, Peroxide treatment, Anhydride treatment, permanganate treatment, Isocyanate treatment, Plasma treatment, gamma radiation [29]. Among the present methods, TDI, peroxide treatment and silane treatments give best properties related to mechanical performances while alkali and acetylation improve the thermal and dimension stability. The most important of all the available techniques will be discussed further in later sections.

\section{Thermal stability problems}

Some specific applications require processing of polymer at high temperatures. A good thermal stability is also desired to withstand the process parameters during flowing through the extruder at high temperatures. This is related more to thermosets. For example, curing of epoxy using aromatic or anhydride hardeners requires high heat treatment of composites to accomplish curing of networks. It is desirable for NFRP to have a curing degree above $90 \%$ to satisfy the application needs. For instance, the use of silane coupling agents is a suitable option available which alters the thermal response of fiber [30]. Nano particles addition in NFRP is a recent field of interest. Studies suggest that nano particles lower the interfacial thermal resistance and provide higher thermal conductivity [31].

\section{Fiber strength problems}

Fiber hydrolysis is the key factor responsible for the loss of strength. Highly acidic and basic treatment can distort the structure of the fiber. On the other hand, high heat treatment can result in depolymerization, hydrolysis, oxidation, dehydration, decarboxylation, and re-crystallization [32]. It is recommended to process or treat fibers in milder conditions. The tensile strength varies greatly when surface treatments are done therefore care must be taken to avoid the problem of loss of 
strength which implies that optimization of every surface treatment/process uses tensile strength as the main feature. As a general rule strong conditions are susceptible for short period of times. Silane treatment causes a little effect on fiber tensile strength as reported [24]. Fiber tenacity loss was also reported by such treatment.

\section{E. Fiber composition}

Cellulose is the major component present in natural fiber and is considered to be most important when processing natural fiber. However, some special applications consider lignin also, especially when designing temperature resistance composites. Almost all stem based natural fibers are cellulose-based with small proportions of others substances. Table 1 shows material contents of some important stem fibers:

It can be seen from the components of fibers, the amount of proportions of cellulose, hemicelluloses, lignin and waxes for natural fibers varies greatly. This depends on the climatic conditions of the origin from where the fiber is grown. The geography is directly related to the composition and properties of the fiber [33]. This difference in properties will lead to different extent of treatments for removal of unwanted materials to improve its compatibility with matrices.

In this context, many researchers use Sodium hydroxide $(\mathrm{NaOH})$ to make the fiber rough thereby reducing these unwanted contents and increase hydrogen bonding from the native cellulose structure $[34,35]$. The later is of importance in the sense of hygroscopic properties of the fiber. Acrylic acid is also reported to be effective in this concern[35]. High-pressure steam is also used by many scientists to alter the surface characteristics by removing the unwanted materials and making it more favorable to polymer matrices[36]. These treatments are quite effective in reducing the amounts but exact treatment conditions cannot be made possible in the first attempt because of the variation in composition.

Table 1: Chemical Composition of some common natural fibers [5].

\begin{tabular}{|c|c|c|c|c|c|}
\hline 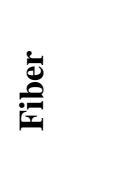 & 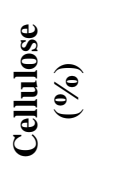 & 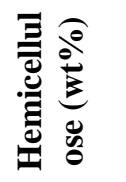 & 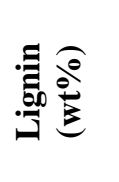 & 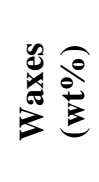 & 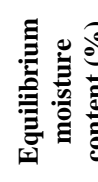 \\
\hline Baggase & 55.2 & 16.8 & 25.3 & - & 8.8 \\
\hline Curaua & 73.6 & 9.9 & 7.5 & - & - \\
\hline Hemp & 68 & 15 & 10 & 0.8 & 9 \\
\hline Jute & $61-71$ & $14-20$ & $12-13$ & 0.5 & 12 \\
\hline $\begin{array}{l}\text { Rice } \\
\text { Husk }\end{array}$ & $35-45$ & $19-25$ & 20 & $14-17$ & - \\
\hline $\begin{array}{l}\text { Rice } \\
\text { Straw }\end{array}$ & $41-57$ & 33 & $8-19$ & $8-38$ & - \\
\hline Ramie & $\begin{array}{l}68.6- \\
76.2\end{array}$ & $13-16$ & $0.6-0.7$ & 0.3 & 9 \\
\hline Abaca & $56-63$ & $20-25$ & $7-9$ & 3 & 15 \\
\hline Coir & $32-43$ & $\begin{array}{c}0.15- \\
0.25\end{array}$ & $40-45$ & - & 10 \\
\hline Oil Palm & 65 & - & 29 & - & \\
\hline
\end{tabular}

\begin{tabular}{lccccc} 
Pineappl & 81 & - & 12.7 & - & 13 \\
e & & & & & \\
Flax & 71 & $18.6-$ & 2.2 & 1.5 & 7 \\
& & 20.6 & & & \\
Bamboo & $26-43$ & 30 & $21-31$ & - & 8.9 \\
Kenaf & 72 & 20.3 & 9 & - & - \\
\hline
\end{tabular}

F. Fiber properties

NFRP properties depend on the properties of fiber; therefore, it is important to know individual fiber properties before using it in composites. The properties of fiber vary and it depends on its chemical composition, dimensions of cells, alignment of fibrils along the length, cellulosic structure and amount, physical attributes and mechanical properties. Table 3 shows the physical and mechanical attributes of some important natural fibers.

Fiber strength can be taken as an important property for use in an application. Usually, the high ratio of length to width is desired which is directly related to the maturity of the fiber. A mature fiber has a perfect ratio with fewer defects on its surface. The elastic behavior of fiber is related to the angle of microfibril along the axis of the fiber. The elastic modulus decreases when this angle is increased. It is also interesting to note that crystallinity of plant fiber is not constant. The crystallinity varies from plant to plant and within the same plant from root to stalk core.

These variations in characteristics of fiber may point out the users for good mixing of fibers before using it in composites.

Table 3 Physical and mechanical properties of natural fibers $[5$, 37, 38].

\begin{tabular}{ccccc}
\hline Fiber & $\begin{array}{c}\text { Tensile } \\
\text { Strength } \\
(\mathbf{M P a})\end{array}$ & $\begin{array}{c}\text { Youngs } \\
\text { Modulus } \\
(\mathbf{G P a})\end{array}$ & $\begin{array}{c}\text { Elongation } \\
\text { at break } \\
(\mathbf{\%})\end{array}$ & $\begin{array}{c}\text { Density } \\
\left(\mathbf{g} / \mathbf{c m}^{2}\right)\end{array}$ \\
\hline Coir & 175 & $4-6$ & 30 & 1.2 \\
Pineapple & $400-627$ & 1.44 & 14.5 & $0.8-1.6$ \\
Bamboo & $140-230$ & $11-17$ & - & $0.6-1.1$ \\
Flax & $345-1035$ & 27.6 & $2.7-3.2$ & 1.5 \\
Jute & $393-773$ & 26.5 & $1.5-1.8$ & 1.3 \\
Kenaf & 930 & 53 & 1.6 & - \\
Sisal & $511-635$ & $9.4-22$ & $2.0-2.5$ & 1.5 \\
Oil Palm & 248 & 3.2 & 25 & $0.7-1.55$ \\
Ramie & 560 & 24.5 & 2.5 & 1.5 \\
Bagasse & 290 & 17 & - & 1.25 \\
Abaca & 400 & 12 & $3-10$ & 1.5 \\
Curaua & $500-1150$ & 11.8 & $3.7-4.3$ & 1.4 \\
Oil Palm & 248 & 3.2 & 25 & $0.7-1.55$ \\
Elephant & 185 & 7.40 & 2.5 & 0.81 \\
grass & & & &
\end{tabular}

\section{DETAILS OF EFFECTIVE TREATMENTS OF FIBER FOR COMPOSITES}

The methods can be broadly classified as two different techniques. Physical methods include heat and without heat extension, corona treatment, plasma treatment and gamma radiation. These treatments do not change the chemical composition of fiber while changes the surface characteristics to a greater extent to enable mechanical bonding. Secondly, more versatile techniques are chemical modifications including 
silane treatment, alkali treatment, acetylation, maleated coupling, enzyme treatment.

\section{A. Corona treatment}

Corona treatment is used for surface modification by oxidation activation. This process changes the surface energy of the fibers. In other words, the polarity of fiber increases by the formation of aldehyde groups on the surface.

Gassan and co-workers treated jute fibers with epoxy [39]. It was concluded by their research that corona treatment increases the overall polarity of the fibers.

Studies on hemp fiber and PP composites were carried by Ragoubi et al;[40]. They concluded higher tensile strength and Young modulus of the composite. SEM analysis revealed improvement in the fiber-matrix adhesion.

Pizzi et al; worked on the treatment time of corona treatment for hemp and flax fibers. It was found that only the treatment for 5 minutes will result in the maximum tensile breaking strength of the composite. After that, the strength value decreases rapidly [41].

As the fiber is three dimensional in nature, the effect of corona treatment is small. The tenacity of fiber has an indirect relation to the corona power as it decreases with increasing power.

\section{B. Plasma treatment.}

In connection with corona treatment, various forms of surface modification could be achieved by using plasma treatment. This treatment introduces cross-linking of the surface while energy could be increase or decrease and free radicals could be produced. Helium cold plasma treatment was done on flax fibers reinforced polyester composites. It was concluded that water permeation was decreased with the increased mechanical stiffness of composite. This was accompanied by good interfacial adhesion of fiber in matrix due to the formation of free radical groups on the surface of fibers [42].

The effect of roughness on the jute fiber due to etching caused by plasma power was observed by Sinha et al; the hydrophobicity of the fiber increases. The fibers were mixed with the polyester matrix for composites to enhance mechanical performance improvement. It was concluded that $10 \mathrm{~min}$ treatment of fiber results in 14\% improvement in strength[43]. Jute fibers were also treated with radio frequency (RF) and lowfrequency (LF) plasma powers by using $\mathrm{O}_{2}$ for composite with the polyester matrix. It was concluded that interlaminar shear strength increases as a result of good adhesion between fibers and matrix. Improved tensile and flexural strength werealso achieved with both plasma systems. RF treatment was found better than LF treatment using $\mathrm{O}_{2}$ in Plasma system [44].

\section{Gamma radiation}

Gamma rays are an electromagnetic radiation produced by radioactive decay. The penetration of gamma rays through the material alters the fibers internal structure, therefore, the strength of fiber itself decreases. Haydaruzzaman and coworkers studied the effects of gamma radiation on jute fiber and PP composites. It was found that $500 \mathrm{krad}$ treatment of both the fiber and matrix give best results of tensile strength, bending strength and impact strength[45].

\section{Silane treatment}

Silane treatment is used in many industrial applications as a coupling agent to improve adhesion between a fiber and polymeric matrix. The coupling reaction is related to the effect of two reactive surface groups. Alkoxy groups allow the coupling agent to bind with the $-\mathrm{OH}$ groups initially, then the alkyl groups increase the compatibility with organic compounds and the hydrophobic character of the surface. This will lead to an increase in the strength of the interface [46, 47]. Figure 3 shows the mechanism of silane treatment of fiber.

Kenaf and abaca fibers composites with polyester resin were made by using silane coupling agent to modify the surface of fibers. The results show an increase in storage modulus of the composites. Tan delta values were reduced as compared to original fiber which shows an increase in interfacial adhesion of fibers within the matrix[48].

Two different types of flax fibers (natural and pulp) were compared for three different types of coupling agents; Vinyl trimethoxy silanes, maleic anhydride, andmaleic anhydride PP copolymer. The last one gave the best results in terms of mechanical properties for both types of fibers, while no changes were seen in the properties by the application of first two agents on the flax fibers[49].

Some studies also suggest for silane treatment in combination with alkali treatment [50].Jute fibers were treated with oligomeric siloxaneto prepare a polyester composite. It was concluded that treatment of only $1 \%$ concentration of such agent can increase the interfacial adhesion of alkali treated fiber thereby increasing tensile strength and flexural strength of the composites.

\section{E. Alkaline treatment}

This is the simplest of all methods available to improve the surface interaction of fiber with the matrix. Surface roughness is improved by chemical modification and cleanness of fiber surface. Many material scientists use this procedure for improvement of NFRP composites.

Sisal fiber reinforced epoxy composites were made after alkali treatment of $0.5 \mathrm{~N}$ Solution. The results showed more rigid composites with less porosity. The compressive strength was enhanced [51]. 


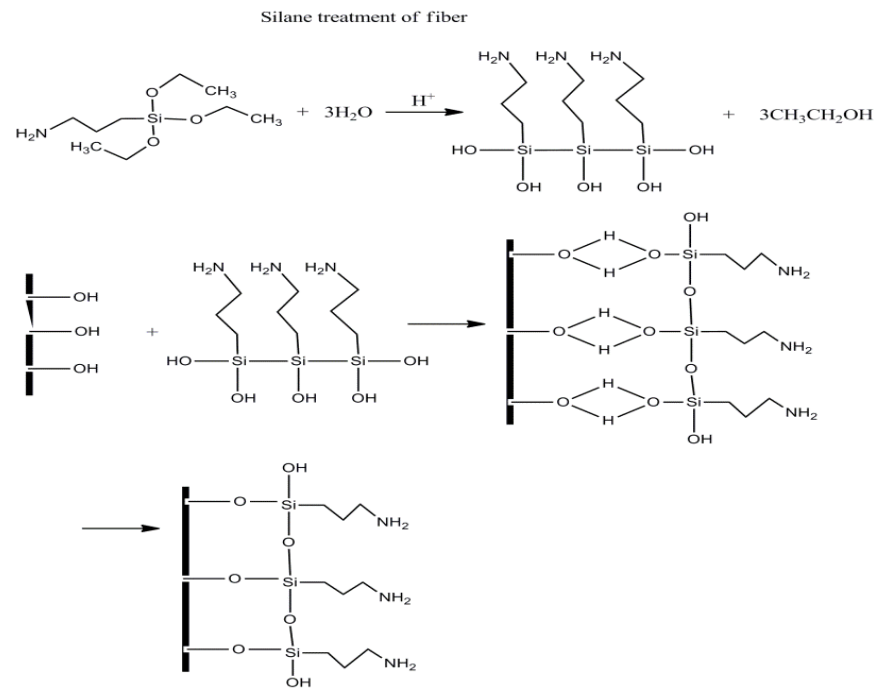

Figure 3 Silane treatment mechanism of natural fiber

Ramie fiber was treated with sodium hydroxide to assess the change of properties. It was discovered that tensile strength was improved by $18 \%$. The fracture strain was also improved approximately three times to that of untreated fiber. This change was due to change of morphology and structure of fiber [52].Jute fiber was subjected to sodium hydroxide treatment. The concentration of $5 \%$ solution increases tenacity, flexural strength, flexural modulus and laminar shear strength[53].Other literature includes ramie fiber[54], sisal fiber [55], jute fibers[56] and coir fibers [57] composites with different polymer matrices. All of the treated fibers show an increase of mechanical properties of composites compared to untreated fiber composites.Figure 4 shows the mechanism of treatment of fiber with $\mathrm{NaOH}$ solution.

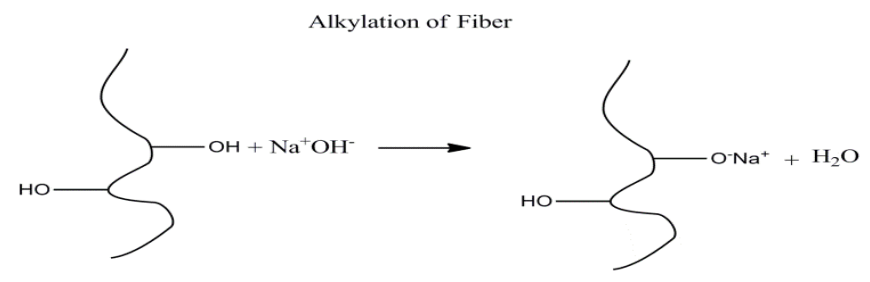

Figure 4 Alkali treatment mechanism of natural fiber

\section{F. Acetylation}

This process is an esterification method which reduces the hygroscopicity of natural fibers and increases the dimensional stability of NFRP. Acetylation changes the surface topography of natural fibers resulting in better free energy surfaces and stress transfer efficiency. This process also removes uncrystalline contents of fibers [58].

Flax fibers were modified by acetylation and reinforced with PP matrix. It was observed that the fibers moisture absorbency properties decrease due to the reduction of $-\mathrm{OH}$ groups of the fiber surface. This has also an effect on the degree of polymerization which decreases slowly until $18 \%$ acetylation. After $18 \%$ contents were acetylated, the polymerization degree decreases rapidly because of the degradation of cellulose [59$62]$. Figure 5 shows the mechanism of fiber treatment with acetylation.

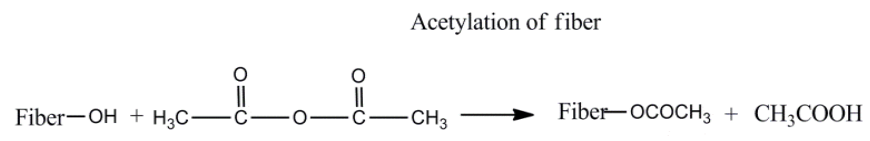

Figure 5. Acetylation of natural fiber

\section{G. Maleated coupling}

Maleated coupling agents are used to enhancing mechanical performance of NFRP. This type of grafting uses the free carbon-carbon unsaturation of the maleic anhydride group to form bonds to the polymer chain and leaving the anhydride group free to react. Due to the presence of the polar anhydride group on the olefin, this makes these polymers good couplers for natural fibers.

Several studies suggest the use of maleic anhydride PP as a coupling agent for NFRP. MAPP of $0.5 \%$ concentration and treatment time of $5 \mathrm{~min}$ was found sufficient to obtain maximum improvement of mechanical properties. Mechanical properties like Youngs and flexural modulus, flexural strength, impact strength and hardness of composites were also improved after the treatment [63]. Figure 6 shows the mechanism of coupling agent treatment of natural fiber.

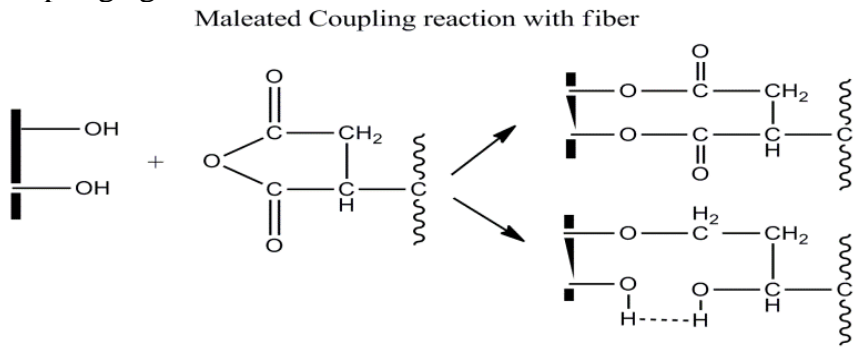

Figure 6 Mechanism of Maleic anhydride treatment of natural fiber

Fatigue and impact loadings of composites also get improvement for MAH-PP treated jute fiber reinforced composite. Fiber-matrix adhesion improves which results in higher dynamic modulus and also reduction in stiffness degradation[76].Many types of composites are reported for a variety of different properties improvement for different fibers. Moisture absorption properties of flax fiber and PP composites [77], thermal and crystallization change of sisal fiber and PP composite [78], surface and water uptake behavior of flax, hemp reinforced PP composite [79], trans-crystallinity of jute fiber and PP composites [80] and dynamic mechanical properties of flax and hemp fiber with PP composites [81].

\section{H. Biological treatment}

The use of enzymes or bacteria to degrade non-cellulosic substances is the most suitable eco-friendly option available. Four kinds of enzymes are used for this purpose; pectin lyase, xylanase, laccase, and cellulose. After this treatment, the structure of fiber loosens and micro-fibril structure opens up with increased fineness for improved fiber/matrix interaction [82]. 
Hemp and flax fibers were treated with enzymes for the production of the composite with thermoplastics. Improvements in the mechanical properties of composites and morphological properties were enhanced[83].

Figure 7 shows how enzymes behave in the surface alteration of natural fiber.

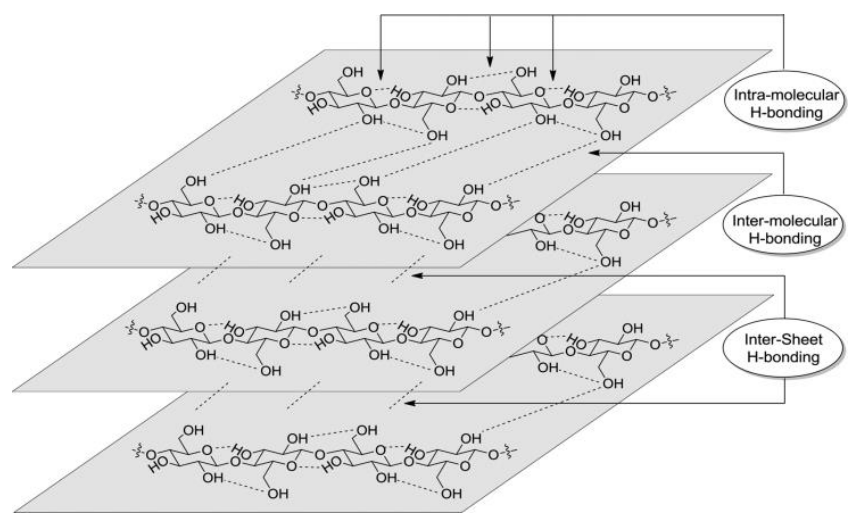

Figure 7 Effects of enzymes on natural fiber

\section{POLYMER MATRICES}

\section{A. Thermoplastics}

The use of thermoplastic polymers for composite lies in their own that they are easily recyclable. There are various studies on using these polymers with fibers as filler. Studies suggest of using 40 to $70 \%$ filler contents. The most commonly used thermoplastics are PP, PE, polystyrene (PS) and polyvinyl chloride (PVC).

Table 4 shows some of the composites of thermoplastics with jute, kenaf, sisal and hemp pretreated with maleicanhydride coupling agent before use, along with mechanical properties reported.

\section{B. Challenges in the application of NFRP.}

The absorption of moisture from atmosphere limits the performance of such composites when exposed to outdoor environments. Color fading of surface and erosion, fungi accumulation, the growth of mold and loss in strength are all results due to the environment[84-87]. These problems are highest on the surface compared to the internal core of the composite as the surface is more saturated with moisture. Hydrophobization of fibers protects the composites potential damage associated with moisture absorption of fibers. Jute fiber treated with gamma-glycidoxypropyltrimethoxy silane and sisal fiber composites with epoxy results in reduced water uptake by composites [88, 89]. Coir and oil palm fibers modified with maleic anhydride polyester shows better results in soil burial test for one year. Mass loss by fungal decay was decreased due to the fact that less water was absorbed by composite surfaces $[90,91]$.

\section{Hybridization}

The incorporation of the third particle for specific property improvement of NFRP is the effective way and promising field. The key issue is to decrease the moisture uptake along with any other mechanical enhancement as reported in the literature. One study was done on kenaf and pineapple leaf fiber reinforced high-density polyethylene composites suggest an increase of tensile and flexural strength of pineapple leaf fiber while kenaf fiber increases impact strength and also reduces the water uptake of the composite [92]. Sisal fiber and polyester resin composite along with the presence of banana fiber result in increased tensile properties of the composite comparatively in the absence of banana fibers [93]. Many researchers have also used nanoparticles of different materials other than natural fibers to increase one or several properties of these NFRP but still, there are enough materials available that can be tried.

\section{CONCLUSION}

The above studies derive the following conclusions:

- $\quad$ NFRP can be made possible by suitable pretreatment of fibers. The most important thing is to remove the unwanted material naturally present in the fiber so that fiber/matrix interaction can be improved.

- The improved properties of the composite are the result of greater fiber and polymer attraction which is made possible by incorporating some coupling agents in the composites.

Table 4 Mechanical properties of composites with different natural fibers reported in the literature

\begin{tabular}{|c|c|c|c|c|c|c|c|c|}
\hline Polymer & Fiber & $\begin{array}{l}\% \text { of } \\
\text { fiber }\end{array}$ & $\begin{array}{l}\text { Tensile } \\
\text { Strength } \\
\mathrm{MPa}\end{array}$ & $\begin{array}{l}\text { Tensile } \\
\text { Modulus } \\
\text { GPa }\end{array}$ & $\begin{array}{l}\text { Flexural } \\
\text { Strength } \mathrm{MPa}\end{array}$ & $\begin{array}{l}\text { Flexural } \\
\text { Modulus GPa }\end{array}$ & $\begin{array}{l}\text { Impact Strength } \\
\text { Izod I /Charpy C }\end{array}$ & Reference \\
\hline \multirow{4}{*}{ Polypropylene } & Jute & 60 & 74 & 11 & 112 & 12 & $195 \mathrm{i}$ & [64] \\
\hline & Hemp & 40 & 52 & 4 & 86 & 4 & $210 \mathrm{i}$ & [65] \\
\hline & Kenaf & 30 & 46 & 5 & 58 & 4 & $39 \mathrm{i}$ & [66] \\
\hline & Sisal & 30 & 28 & 2.1 & 62 & 3.2 & $14 \mathrm{i}$ & [67] \\
\hline \multirow{4}{*}{ HDPE } & Jute & 30 & 34.42 & 1.03 & 31.97 & 1.34 & & {$[68]$} \\
\hline & Hemp & 35 & 31.4 & 2.72 & & & $97.5 \mathrm{i}$ & [69] \\
\hline & Kenaf & 30 & 12 & 0.72 & 28 & 1.6 & & {$[70,71]$} \\
\hline & Sisal & 30 & 44.3 & 1.24 & 59.2 & 2.856 & $68.4 \mathrm{i}$ & [72] \\
\hline \multirow{2}{*}{ LDPE } & Jute & 30 & 27.7 & 1.6 & 10.7 & 1.82 & $8.9 \mathrm{i}$ & {$[73,74]$} \\
\hline & Hemp & 40 & 16 & 0.9 & {$[73]$} & & $14 \mathrm{c}$ & [75] \\
\hline
\end{tabular}


- $\quad$ The type of fiber is an important area to be considered for NFRP. Even with the same proportion of two different fibers for the same polymer, there seems to be a very high difference in properties even if the fibers are pretreated with thesame coupling agent. The results are very different from the two composites. The difference in the fiber characteristics, cellulose content or structure may be considered as affecting the composite performance along with binding of the fibers to the resin.

- Radiation treatment (gamma and corona) alters the moisture uptake of fibers which eventually results in more linking points between fiber and matrix. As the constituents of each fiber vary, care must be taken in selecting the process parameters to avoid cellulose degradation. Optimization of process conditions is suggested before using this for NFRP manufacturing.

- Biological treatment is the most eco-friendly option and is recommended over the radiation treatment if the time for processing is not a key issue.

- Hybridization is an effective way of improving the composite properties more as compared to single fiber type. Especially, nanoparticles distribution along the matrix. Low specific gravity and higher surface area of nanoparticles, results in a good dispersion.

- Though NFRP has played an important role in replacing many synthetic made materials, further research is still required in improving the moisture resistance and fire retardancy to increase its application area.

\section{REFERENCES}

K. M. Mohanty AK, Sahoo S, Hinrichsen G., "Effect of CHemical Modification on the performance of biodegradeable jute yarn-Biopol (R) Composites. ," Journal of Material Science vol. 35, no. 10, pp. 25892595, 2000.

L. C. Rozman HD, Ismail H, Mohd Ishak ZA., "The effect of coupling agents on the mechanical and physical properties of oil palm empty fruit bunchpolypropylene composites," Polym Int, vol. 49, pp. 1273-8, 2000.

S. R. Carroll DR, Siringano AM, Saindon RM, Gose SC, Friedman MA, "Structural properties of recycled plastic/sawdust lumber decking planks," Res Cons Recycl, vol. 31, pp. 241-51, 2001.

C. S. Netravali AN, "Composites get greener," Mater Tod, vol. 6, pp. 22-6, 2003.

A. K. B. Omar Faruka, Hans-Peter Fink, Mohini Sain, "Biocomposites reinforced with natural fibers: 20002010," Progress in Polymer Science, vol. 37, pp. 1552 1596, 2012.

T. S. Joseph K, Pavithran C, "Effect of chemical treatment on the tensile properties of short sisal fibrereinforced polyethylene composites," Polymer, vol. 37, no. 5, pp. 139-49, 1996.
[7]

[8]

J. K. Joseph PV, Thomas S., "Effect of processing variables on the mechanical properties of sisal-fiberreinforced polypropylene composites," Compos Sci Technol vol. 59, pp. 1625-40, 1999.

R.-L. J. Canchè-Escamilla G, Cuich-Cupul JI, Mendizabal E, Puig JE, Herrera-Franco PJ., "Flexural, impact and compressive properties of a rigidthermoplastic matrix/cellulose fiber reinforced composites," Compos Part A, vol. 33, no. 539-49, 2002.

K. R. Nair KCM, Thomas S, Schit SC, Ramamurthy K.. "Rheological behavior of short sisal fiberreinforced polystyrene composites," Compos Part A, vol. 31, pp. 1231-40, 2000.

D. L. Joshi SV, Mohanty AK, Arora S., "Are natural fiber composites environmentally superior to glass fiber reinforced composites?," Compos Part A, vol. 35, no. 371-6, 2004.

W. I. Selke SE, " Wood fiber/polyolefin composites," Compos Part A, vol. 35, pp. 321-6., 2004.

P. R. Chen HL, "Composite of polyethylene and kenaf, a natural cellulose fiber," J Appl Polym Sci, vol. 54, pp. 1781-3, 1994.

T. D. N. La Mantia FP, Morreale M, Vaca-Garcia C., "Green composites of organic materials and recycled post-consumer polyethylene," Polym Int, vol. 53, pp. 1888-91, 2004.

R. H. Khalil HPSA, Ahmad MN, Ismail H. , "Acetylated plant-fiberreinforced polyester composites: a study of mechanical, hygrothermal, and aging characteristics," Polym Plast Tech Eng, vol. 39, pp. 757-81, 2000.

M. M. La Mantia FP, Mohd Ishak ZA. , "Processing and mechanical properties of organic fillerpolypropylene composites," J Appl Polym Sci, vol. 96, pp. 1906-13, 2005.

[16] W. M. Li TQ, "Rheology of HDPE-wood composites. I. Steady state shear and extensional flow," Compos Part A vol. 35, pp. 303-11, 2004.

[17] M. Chrysanthos, "Novel biobased epoxy networks derived from renewable resources: Structure-property relationships," $\mathrm{PhD}$, L'institut national des sciences appliquées de Lyon, 2012.

[18] M. M. La Mantia FP, " Improving the properties of polypropylene-wood flour composites by utilization of maleated adhesion promoters.," Compos Interf, vol. 14, pp. 685-98, 2007.

[19] R. P. Martinie L, Roussel N "Rheology of fibre reinforced cementitious materials: classification and prediction," CemConcr Res, vol. 40, no. 2, pp. 226234, 2010.

[20] T. Khelifi, A. LecomptePerrot, and G. Ausias, "Mechanical enhancement of cement-stabilized soil by flax fibre reinforcement and extrusion processing," Materials and Structures, vol. 49, no. 4, pp. 1143-11, 2016.

[21] U. Rowell RM. Cambridge, "Natural fibres: types and properties. ," (Properties and performance of natural- 
fibre composites. Woodhead Publishing, 2008, p.^pp. Pages.

[22] M. H. Donath S, Mai C., "Creating water-repellent effects on wood by treatment with silanes," Holzforschung, vol. 60, pp. 40-6, 2006.

[23] B. S. Abdelmouleh M, Belgacem MN, Duarte AP, Ben Salah A, Gandini A, "Modification of cellulosic fibres with functionalised silanes: development of surface properties," Int J Adhes Adhes, vol. 24, no. 43-54, 2004.

[24] T. Doan, "Investigation on jute fibres and their composites based on polypropylene and epoxy matrices," $\mathrm{PhD}$ thesis, Technischen Universität, Dresden, 2006.

[25] B. S. Abdelmouleh M, Belgacem MN, Duarte AP, Ben Salah A, Gandini A, "Modification of cellulosic fibres with functionalised silanes: development of surface properties," Int J Adhes Adhes, vol. 24, pp. 43-54, 2004.

[26] P. D. Biagiotti J, Torre L, Kenny JM., " A systematic investigation on the influence of the chemical treatment of natural fibers on the properties of their polymer matrix composites," Polym Compos, vol. 25, pp. 470-9, 2004.

[27] C. A. S. H. Yanjun Xie, Zefang Xiao, Holger Militz, Carsten Mai "Silane coupling agents used for natural fiber/polymer composites: A review," Composites: Part A, vol. 41, pp. 806-819, 2010.

[28] M. G. A. E. K.L. Pickering, T.M. Le, "A review of recent developments in natural fibre composites and their mechanical performance," Composites: Part A, vol. 83, pp. 98-112, 2016.

[29] M. M. F.P. La Mantia, "Green Composites- A brief review," Compos Part A, vol. 42, pp. 579-588, 2011.

[30] F. B. Arbelaiz A, Ramos JA, Mondragon I., "Thermal and crystallization studies of short flax fibre reinforced polypropylene matrix composites : effect of treatments," Thermochim Acta, vol. 440, pp. 111-21, 2006.

[31] N. Hu, Composites and Their Properties. Croatia: Janeza Trdine 9, 51000 Rijeka, Croatia, 2012.

[32] B. A. Gassan J, "Thermal degradation of flax and jute fibers," J Appl Polym Sci vol. 82, pp. 1417-22, 2001.

[33] B. A. M. Mustafa A, Shuhimi FF, Ismail N, Amiruddin H, Umehara N., "Selection and verification of kenaf fibres as an alternative friction material using Weighted Decision Matrix method," Mater Des, vol. 67, pp. 577-82, 2015.

[34] K. H. Lee BH, Yu WR., "Fabrication of long and discontinuous natural fibre reinforced polypropylene biocomposites and their mechanical properties," Fiber Polym, vol. 10, pp. 83-90, 2009.

[35] P. S. Li X, Tabil LG., "A study on flax fiber-reinforced polyethylene biocomposites," Appl Eng Agr, vol. 25, pp. 525-31, 2009.

[36] K. Satyanarayana, "Steam Explosion-a boon for value addition to renewable resources " Metal news, vol. 22, pp. 35-40, 2004.
[37] A. V. R. Prasad, K. B. Rao, K. M. Rao, K. Ramanaiah, and S. P. K. Gudapati, "Influence of Nanoclay on the Mechanical Performance of Wild Cane Grass FiberReinforced Polyester Nanocomposites," International Journal of Polymer Anal. Charact, vol. 20, pp. 541556, 2015.

[38] K. M. M. Rao, A. V. R. Prasad, M. N. V. R. Babu, K. M. Rao, and A. V. S. S. K. S. Gupta, "Tensile properties of elephant grass fiber reinforced polyester composites," Journal of Materials Science, journal article vol. 42, no. 9, pp. 3266-3272, May 012007.

[39] G. V. Gassan J, "Effects of corona discharge and UV treatment on the properties of jute-fibre epoxy composites," Composites Science and Technology, vol. 60, pp. 2857-63, 2000.

[40] B. D. Ragoubi M, Molina S, George B, Merlin A., " Impact

of corona treated hemp fibres onto mechanical properties of polypropylene composites made thereof," Industrial Crops and Products, vol. 31, pp. 344-9, 2010.

[41] K. R. Pizzi A, Lecoanet F, Massetau B, Carpentier D, Krebs A, Loiseau F, Molina S, Ragoubi M., " High resin content natural matrix-natural fibre biocomposites.," Industrial Crops and Products, vol. 30, pp. 235-40, 2009.

[42] G. F. Marais S, Bonnesoeur A, Grenet J, PoncinEpaillard F, Morvan C, Metayer M. ;:, "Unsaturated polyester composites reinforced with flax fibers: effect of cold plasma and autoclave treatments on mechanical and permeation properties.," Composites Part A: Applied Science and Manufacturing, vol. 36, no. 975-86, 2005.

[43] P. S. Sinha E, "Effect of plasma treatment on structure, wettability of jute fiber and flexural strength of its composite," Journal of Composite Materials, vol. 43, pp. 1791-802, 2009.

[44] S. M. Seki Y, Sever K, Erden S, Gulec HA., "Effect of the low and radio frequency oxygen plasma treatment of jute fiber on mechanical properties of jute fiber/polyester composite.," Fibers and Polymers, vol. 11, pp. 1159-64, 2010.

[45] R. K. Haydaruzzaman, MubarakA.Khan, A.H.Khan, M.A.Hossain, "Effect ofgammaradiationontheperformanceofjutefabricsreinforced polypropylenecomposites," Radiation PhysicsandChemistry, vol. 78, pp. 986-993, 2009.

[46] M. A. Arsène, K. Bilba, and A. Ouensanga, "Study of banana and coconut fibers: botanical composition, thermal degradation and textural observations," Bioressour Technol, vol. 68, no. 1, pp. 58-68, 2007.

[47] L. A. Pothan and S. Thomas, "Polarity parameters and dynamic mechanical behaviour of chemically modified banana fiber reinforced polyester composites," Composites Science and Technology, vol. 63, no. 9, pp. 1231-1240, 2003/07/01/ 2003.

[48] K. S. Xu Y, Hosoi K, Kawai T, Kuroda S., "Thermomechanical properties of the silanized- 
kenaf/polystyrene composites," EXPRESS Polymer Letters, vol. 3, pp. 657-64, 2009.

[49] A. A. Cantero G, Llano-Ponte R, Mondragon I., "Effects of fibre treatment on wettability and mechanical behavior of flax/polypropylene composites," Composites Science and Technology, vol. 63, pp. 1247-54, 2003.

[50] Y. Seki, "Innovative multifunctional siloxane treatment of jute fiber surface and its effect on the mechanical properties of jute/thermoset composites," Materials Science and Engineering A, vol. 508, pp. 247-252, 2009.

[51] B. ETN, "The effect of alkali treatment on the adhesion characteristics of sisal fibres.," Applied Composite Materials, vol. 7, pp. 331-9, 2000.

[52] S. M. Goda K, Gomes A, Kaji T, Ohgi J, " Improvement of plant based natural fibers for toughening green composites-effect of load application during mercerization of ramie fibers," Composites Part A: Applied Science and Manufacturing, vol. 37, pp. 2213-20, 2006.

[53] S. B. Ray D, Rana AK, Bose NR., "The mechanical properties of vinylester resin matrix composites reinforced with alkali-treated jute fibres," Composites Part A: Applied Science and Manufacturing, vol. 32, pp. 119-27, 2001.

[54] S. N. Qin C, Xiuyuan N, Peijs T., "The effect of fibre volume fraction and mercerization on the properties of all-cellulose composites," Carbohydrate Polymers, vol. 71, pp. 458-67, 2008.

[55] A. R. Iannace S, Nicolais L. , "Effect of processing conditions on dimensions of sisal fibers in thermoplastic biodegradable composites," Journal of Applied Polymer Science, vol. 79, pp. 1084-91, 2001.

[56] K. M. Mohanty AK, Misra M, Hinrichsen G., "Natural fibre reinforced biodegradable matrix composite: effect of surface modification of jute on the performance of jute-biopol composites," PMSE Preprints, vol. 82, pp. 29-30, 2000.

[57] T. S. Rout J, Nayak SK, Misra M, Mohanty AK., "Scanning electron microscopy study of chemically modified coir fibers," Journal of Applied Polymer Science, vol. 79, pp. 1169-77, 2001.

[58] Z. N. Tserki V, Simon F, Panayiotou C., " A study of the effect of acetylation and propionylation surface treatments on natural fibres," Composites Part A: Applied Science and Manufacturing, vol. 36, pp. 1110-8, 2005.

[59] B. C. Zafeiropoulos NE, Hodgkinson JM., "Engineering and characterisation of the interface in flax fibre/polypropylene composite materials. Part II. The effect of surface treatments on the interface," Composites Part A: Applied Science and Manufacturing, vol. 33, pp. 1185-90, 2002.

[60] W. D. Zafeiropoulos NE, Baillie CA, Matthews FL., "Engineering and characterisation of the interface in flax fibre/polypropylene composite materials. Part I. Development and investigation of surface treatments.," Composites Part A: Applied Science and Manufacturing, vol. 33, pp. 1083-93, 2002.

[61] B. C. Zafeiropoulos NE, " A study of the effect of surface treatments on the tensile strength of flax fibres: Part II. Application of Weibull statistics," Composites Part A: Applied Science and Manufacturing, vol. 38, pp. 629-38, 2007.

[62] D. G. Zafeiropoulos NE, Baillie CA., "A study of the effect of surface treatments on the tensile strength of flax fibres: Part I. Application of Gaussian statistics.," Composites Part A: Applied Science and Manufacturing, vol. 38, pp. 621-8, 2007.

[63] N. J. Mishra S, Patil YP., "The compatibilising effect of maleic anhydride on swelling and mechanical properties of plantfiber- reinforced novolac composites," Composites Science and Technology, vol. 60, pp. 1729-35, 2000.

[64] M. A. Rana AK, Mitra BC, Jacobson R, Rowell R, Banerjee AN, "Short jute fiber-reinforced polypropylene composites: effect of compatibilizer," Journal of Applied Polymer Science, vol. 69, no. 2, pp. 329-38, 1998.

[65] S. P. Sain M, Law S, Bouilloux A, " Interface modification and mechanical properties of natural fiber-polyolefin composite products," J Reinf Plast Comp, vol. 24, no. 2, pp. 121-30, 2005

[66] M. Zampalonib, , F. Pourboghrata, S.A. Yankovicha, B.N. Rodgersa, J. Moorea, L.T. Drzalb, A.K. Mohantyc, M. Misrab, "Kenaf natural fiber reinforced polypropylene composites: A discussion on manufacturing problems and solutions," Composites Part A: Applied Science and Manufacturing, vol. 38, no. 6, pp. 1569-1580, 2007.

[67] Nitinat Suppakarn, Kasama Jarukumjorn, "Natural fiber composites Mechanical properties and flammability of sisal/PP composites: Effect of flame retardant type and content," Composites Part B: Engineering, vol. 40, no. 7, pp. 613-618, 2009.

[68] S. N. M. Amanda C. Lima, Kestur G. Satyanarayana, "Recycled Polyethylene Composites Reinforced with Jute Fabric from Sackcloth: Part I-Preparation and Preliminary Assessment," Journal of Polymers and the Environment, vol. 20, no. 1, pp. 245-253, 2012.

[69] S. Oza, R. Wang, and D. N. Lu, "Thermal and Mechanical Properties of Recycled High Density Polyethylene/hemp Fiber Composites," International Journal of Applied Science and Technology, vol. 1, no. 5, 2011.

[70] X. V. Cao, H. Ismail, A. A. Rashid, T. Takeichi, and T. Vo-Huu, "Mechanical properties and water absorption of kenaf powder filled recycled high density polyethylene/natural rubber biocomposites using mape as a compatibilizer " Bio Resources, vol. 6, no. 3, pp. 3260-3271, 2011.

[71] H. Ismail, H. abdullah, and A. bakar, "Kenaf Core Reinforced High-density Polyethylene/Soya Powder Composites: The Effects of Filler Loading and 
Compatibilizer," Journal of Reinforced plastics and composites, vol. 29, , no. 16, p. 2489_9, 2010.

[72] S. K. N. Smita Mohanty, "Interfacial, dynamic mechanical, and thermal fiber reinforced behavior of MAPE treated sisal fiber reinforced HDPE composites," Journal of applied polymer science vol. 102, no. 4, pp. 3306-3315, 2006.

[73] G. Sarkhel and A. Choudhury, "Dynamic mechanical and thermal properties of PE-EPDM based jute fiber composites," Journal of applied polymer Science, vol. 108, no. 6, pp. 3442-3453, 2008.

[74] K. sever, "The Improvement of Mechanical Properties of Jute Fiber/LDPE Composites by Fiber Surface Treatment," Journal of Reinforced plastics and composites, vol. 29, no. 13, pp. 1921-9, 2010.

[75] J. A. N. Nicole-Lee M. Robertson, Kirill Alemaskin, John D. Wolodko, "Mechanical performance and moisture absorption of various natural fiber reinforced thermoplastic composites," Journal of Applied Polymer Science, vol. 130, no. 2, 2013.

[76] B. A. Gassan J, "Possibilities to improve the properties of natural fiber reinforced plastics by fiber modification-jute polypropylene composites," Applied Composite Materials, vol. 7, pp. 373-85, 2000.

[77] L. T. Aranberri-Askargorta I, Bismarck A. , "Wetting behavior of flax fibers as reinforcement for polypropylene," Journal of Colloid and Interface Science, vol. 263, pp. 580-9, 2003.

[78] J. K. Joseph PV, Thomas S, Pillai CKS, Prasad VS, Groeninckx G, Sarkissova M., "The thermal and crystallisation studies of short sisal fibre reinforced polypropylene composites.," Composites Part A: Applied Science and Manufacturing, vol. 34, pp. 25366, 2003.

[79] A.-A. I. Bismarck A, Springer J, Lampke T, Wielage B, Stamboulis A, Shenderovich I, Limbach HH., "Surface characterization of flax, hemp and cellulose fibers; surface properties and the water uptake behavior," Polymer Composites, vol. 23, pp. 872-94, 2002.

[80] G. J. Bledzki AK, Mildner I., "Transcrystallization of polypropylene on different modified jute fibers," Composite Interfaces, vol. 8, pp. 443-52, 2001.

[81] L. T. Wielage B, Utschick H, Soergel F., "Processing of natural-fibre reinforced polymers and the resulting dynamicmechanical properties.," Journal of Materials Processing Technology, vol. 139, pp. 140-6, 2003.

[82] L. Liu, L. Cheng, L. Huang, and J. Yu, "Enzymatic treatment of mechanochemical modified Natural Bamboo Fibers," Fibers and Polymers vol. 13, no. 5, pp. 600-605, 2012.

[83] T. B. Lipp-Symonowicz B, Wolukanis A, Wrzosek H., " Influence of enzymatic treatment on the flax fibre morphological structure, physico-chemical properties and metrological parameters of yarn," Fibres \& Textiles in Eastern Europe, vol. 12, pp. 61-5, 2004.
[84] W. M. Schirp A, " Influence of fungal decay and moisture absorption on mechanical properties of extruded wood-plastic composites," Wood Fiber Sci, vol. 37, pp. 643-52, 2005.

[85] M. M. Mohanty AK, Drzal LT., "Natural fibers, biopolymers, and biocomposites," Taylor \& Francis, 2005.

[86] S. A and W. MP, "Fungal degradation of wood-plastic composites and evaluation using dynamic mechanical analysis," Journal of Applied Polymer Science, vol. 99, pp. 3138-46, 2006.

[87] L.-R. MG, O.-R. HG, F.-T. FJ, G.-E. S, C.-G. MA, and S.-G. JA, "Evaluation of accelerated decay of wood plastic composites by Xylophagus fungi," Int Biodeter Biodegr, vol. 63, pp. 1030-5, 2009.

[88] B. ETN and A. MP, "The effect of silane treatment on the mechanical and physical properties of sisal-epoxy composites," Composites Science and Technology, vol. 41, no. 2, pp. 165-78, 1991.

[89] B. A. Gassan J, "Effect of moisture content on the properties of silanized jute-epoxy composites.," Polymer Composites, vol. 18, pp. 179-84, 1997.

[90] I. RE and C. CM, "Biological resistance of polyethylene composites made with chemically modified fiber or flour. ," in Proceedings of the 6th pacific rim bio-based composites symposium, Portland, OR, USA, 2002, pp. 574-84.

[91] H. CAS and A. K. HPS., "The effect of environmental exposure upon the mechanical properties of coir and oil palm fiber reinforced composites," Journal of Applied Polymer Science, vol. 77, pp. 1322-30, 2000.

[92] A. IS, Z. ES, A. K, S. SM, and K. MD, "Mechanical properties and water absorption behavior of hybridized kenaf/pineapple leaf fibrereinforced highdensity polyethylene composite," J Compos Mater, vol. 47, no. 8, pp. 979-90, 2012.

[93] I. M, J. K, and T. S, "Mechanical performance of short banana/sisal hybrid fiber reinforced polyester composites," J Reinf Plast Compos, vol. 29, no. 1, pp. 12-29, 2010.

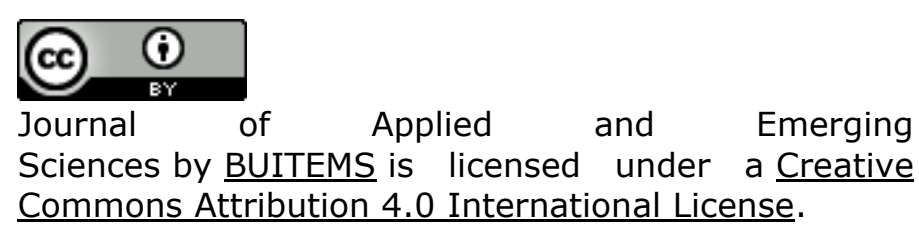

